\title{
Vegetation Analysis, Distribution of Seagrasses and Their relationship to Sediment type in Hurghada and Safaga Harbors, Red Sea
}

\author{
Ahmed A. Khalafallah ${ }^{a}$, Mahmoud A. Dar ${ }^{b}$, Sameh A. El-Kafrawy ${ }^{c}$, Soad. A Sheteawi ${ }^{a}$ \\ and Basma, SH. Essa ${ }^{a}$
}

\author{
${ }^{a}$ Bot. Department., Faculty of women for Arts, Science and Education, Ain Shams \\ University, \\ ${ }^{\mathrm{b}}$ National Institute of Oceanography and Fisheries (NIOF), Hurghada \\ ${ }^{\mathrm{c}}$ National Authority for Remote Sensing \& Space Sciences
}

\begin{abstract}
The present work aimed to study the floristic composition, vegetation analysis, distribution of seagrasses and their relationship with sediment type in Red Sea. Forty stands of seagrass beds distributed in four sites located at Hurghada and Safaga Harbors were investigated. Five seagrasses were identified in the 40 stands; Halophila stipulacea (Forssk.) Asch., Halodule uninervis (Forssk.) Boiss., Halophila ovals (R.Br.) Hook. f., Thalassodendron ciliatum (Forssk.) Hartog and Syringodium isoetifolium (Forssk.) Hartog. All recorded seagrasses are belonging to tropical indo-pacific bioregion. Application of TWINSPAN and DECORANA, as classification and ordination techniques to the 40 stands resulted in five vegetation groups. Sediment of the investigated stands mainly constructed from fine sand. In addition, the correlation coefficient matrix showed that $H$. uninervis and $H$. ovalis prefer presence in sandy sediments, but Th. ciliatum positively correlated to total organic matter. On the other hand, H. stipulacea positively correlated with carbonates. These results are significant as a data base for management and conservation. Recent techniques as remote sensing integrated with field survey is recommended for monitoring these communities to give a clear view on spatial distribution of seagrasses on a large scale along Red Sea.
\end{abstract}

Keywords: Seagrasses, TWINSPAN, Sediment, Hurgada, Safaga, Red Sea.

\section{Introduction}

Plant community plays an important role in sustainable management by maintaining biodiversity and conserving the environment (Kandi et al., 2011). A major objective of most plant community ecology studies has been to identify patterns of species composition and distribution and to interpret these patterns in relation to known or presumed gradients in the environment (Fried, 2008). Quantitative analysis, especially quantitative classification methods and ordination techniques, has been widely used to indicate the ecological relationships between vegetation and the environment (Shehata and Galal, 2015). 
Moreover, floristic studies are not only important to know the variety of plants present in an area, but also socio-economically significant. They provide shelter, food, medicine and other requirements for the human being and other species of that area.

Foundation species, or those species that by effectiveness of their physical characteristics provide the habitat for ecological communities (Dayton, 1972; Hughes et al., 2009), reinforce biodiversity through their facilitative effects on associated species (Ellison $\boldsymbol{e t}$ al., 2005). Example of foundation species include canopy forming plants that provide habitat for a range of species (Ellison $\boldsymbol{e t}$ al., 2005). Because the services that foundation species provide can be impacted long before the species itself disappears (Ellison $\boldsymbol{e t}$ al., 2005), declines in foundation species may also threaten the associated organisms. Furthermore, alternate interactions between foundation species and their associates (Stachowicz and Hay, 1996; Bracken et al., 2007) suggest that it may be necessary to include both in any attempt to conserve either one. Here, we discuss floristic composition of seagrasses-marine flowering plants that act as foundation species in both temperate and tropical shallow water systems worldwide-in an effort to increase awareness of the importance of seagrass ecosystems.

Seagrass is one of the richest and most significant important coastal habitats and ecologically they are important marine species from all trophic levels (Bologna et al., 2013). They are flowering plants belonging to class Monocotyledoneae, growing, flowering and seedling under water, evolving from terrestrial origin and re-entered the sea millions years ago (Duke et al., 2007; Heck et al., 2008). According to Barbier et al. (2011), seagrsses can provide additional services where, the leaves act as a filter, clearing the water of suspended sediments, leaves, roots and rhizomes take up and cycle nutrients. The complex root structure of seagrass beds secures and stabilizes sediments that providing essential shoreline protection and reduction of coastal erosion from extreme storm events (Bjork et al., 2008). Seagrasses leaves form a three-dimensional habitat creating shelter for many other marine species. The leaves serve as a surface for attachment to a wide variety of small encrusting algae and animals. These in turn provide an important food source for larger seagrass-associated animals. In addition, they are a nursery ground for juvenile and larval stages of many commercial, recreational and subsistence fish and shellfish (Heck et al., 2003).

Synoptic studies to date have examined the distribution, status and trends of seagrass habitat, and have clearly indicated that seagrasses are declining globally (Waycott $\boldsymbol{e t}$ al., 2009). A synthesis of 215 published studies showed that seagrass habitat disappeared worldwide at a rate of $110 \mathrm{~km}^{2}$ per year between 1980 and 2006 (Waycott et al., 2009). In addition, Human populations in coastal areas continue to increase and by $2025,75 \%$ of the 
global population is projected to live in coastal areas (Bulleri and Chapman, 2010). Growing coastal populations are frequently accompanied by growing development pressure in these areas, converting previous vegetated systems to impervious unvegetated areas by constructing buildings, paving roads, and armoring shorelines with riprap and bulkheads. In addition, a combination of factors, including coastal development and declining water quality, contributed to the loss of over $50 \%$ of the seagrasses in Cockburn Sound, Australia (Walker et al., 2006). Intense grazing by Canada geese (Branta canadensis) resulted in the loss of $96 \%$ of the seagrass at one site in New Hampshire (Short et al., 2006). Due to their sensitivity to various environmental stressors, seagrasses have been proposed as biological indicators of changing coastal conditions (Orth et al., 2006).

It is important to document seagrass species diversity and distribution and to identify areas requiring conservation measures before significant areas and species are lost. Determining the extent of seagrass areas and the ecosystem values of seagrasses is now possible on a local scale for use by coastal zone managers to aid planning and development decisions. Knowledge of Egyptian seagrass distributions is still too limited for broad scale protection and management while human activities increasingly steady increase. Such information is needed to minimize future impacts on seagrass habitats. Therefore, the current plan aims to study the floristic composition, vegetation analysis, distribution of seagrasses and their interaction with sediment in representative locations at Hurghada and Safaga Harbors.

\section{Materials and Methods}

\subsection{Study sites:}

Seagrass beds were sampled in four localities at Hurghada and Safaga Harbores. The studied sites were divided into 40 stands. Each locality were divided to; 13 stands in Hurghada ; 10 stands in Safaga Fishing port; 7 stands in Gasous and 10 stands in Wadi Quiah . The geographical location of each site was recorded by using GPS model Trimbel Juno SD and represented by figure (1).

The study area characterized by hot and dry climate, where the annual mean of maximum and minimum temperature is 28.8 and $20.6{ }^{\circ} \mathrm{C}$, relative humidity is 49.3 and the annual mean of rainfall is $0.4 \mathrm{~mm}$.

\subsection{Floristic analysis}

Quadrate method as a non destructive method were used as described by English $\boldsymbol{e t}$ al. (1997) to collect seagrasses samples using snorkeling. The quadrate dimensions used were 
$0.5 \times 0.5 \mathrm{~m}$. Seagrasses samples were transferred in ice box to the laboratory for identification. The Seagrasses species were separated and identified according to den Hartog (1970), Green and Short (2003), Boulos (2005), Short et al. (2006) and El Shaffai (2011). Vousher specimens were kept in the herbarium of Botany Department, Women Faculty, Ain Shams University.

The global geographical distribution of the recorded seagrasses was determined according to Short et al. (2007). The global distribution (i.e. floristic regions) is coded as follows: TA: Tropical Atlantic, ME: Mediterranean, TI-P: Tropical Indo-Pacific, TNP: Temperate North Pacific and TSO: Temperate Southern Oceans.

\subsection{Vegetation analysis}

\subsubsection{Multivariate analysis}

TheTwo-way indicator species analysis (TWINSPAN), as a classification technique, and Detrended Correspondence Analysis (DCA), as an ordination technique, were applied to the matrix of presence estimates of 5 species in 40 stands in seagrass beds. TWINSPAN is a two-way classification FORTRAN program that constructs a key to the sample classification by identifying one to several species that are particularly diagnostic of each division in the classification. The most significant new feature is that the program first constructs a classification of samples, and then uses this classification to obtain a classification of species according to their ecological preferences (Hill, 1979a; Gauch and Whittaker, 1981). DCA is a FORTRAN program for detrended correspondence analysis and reciprocal averaging. It was applied as a mean of axis construction to achieve a two-dimentional ordination of species and stands (Hill, 1979b; Hill and Gauch, 1980). 


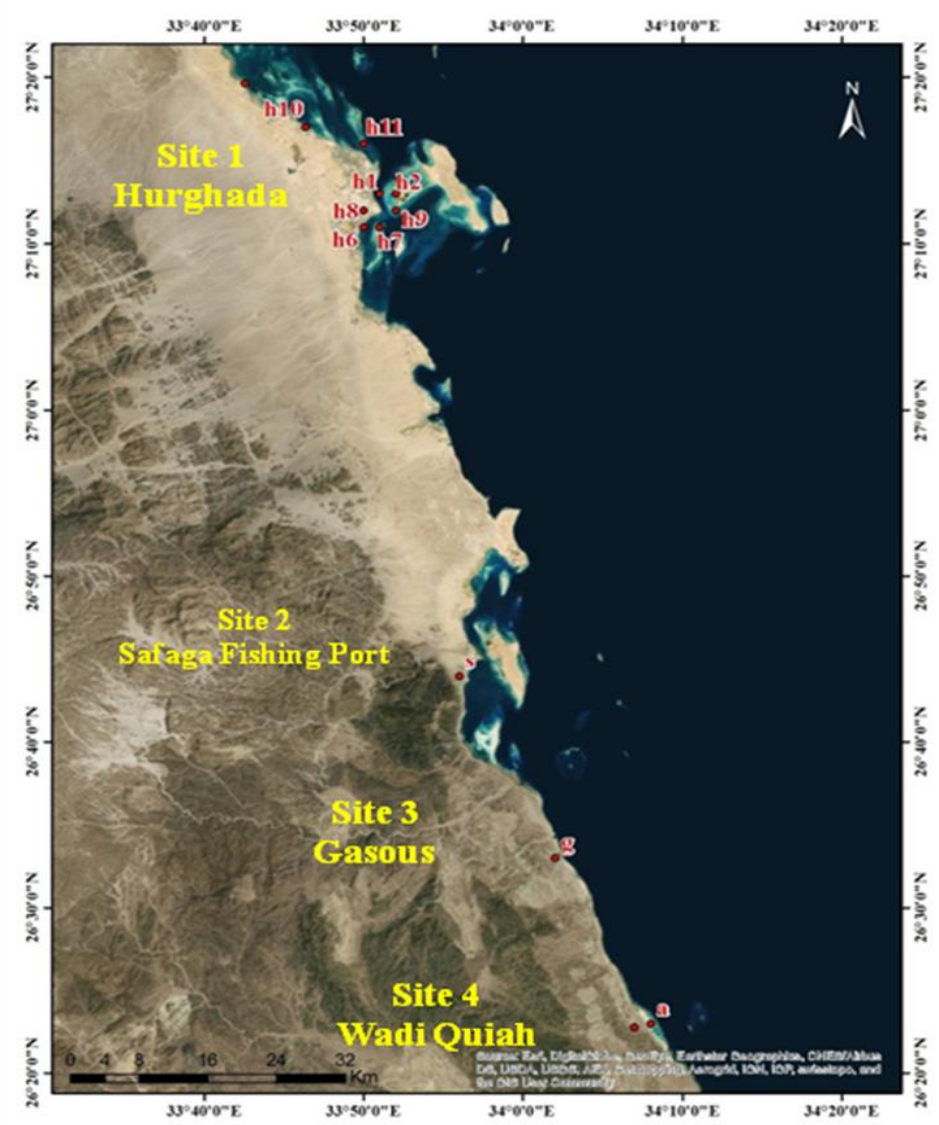

Fig. 1: Map of the four locations of study in Hurgada and Safaga Harbors.

\subsection{Sediment grain size analyses}

The sediment samples were air-dried, disaggregated then sieved through a stainless steel mesh to differentiate the particle-size fractions. The grain-size analyses of these samples were performed using dry method depending upon Wentworth Scale (Folk 1974).

\subsection{Carbonate contents, total organic matter (TOM) and total silicates determination in sediments}

The total carbonate contents were determined by treating one gram of each of the powdered bulk samples with $12 \%$ Glacial acetic acid. The remaining insoluble residue after acid washing was weighted and the carbonate percentages were calculated as percentage (Dar et al., 2016) according the equation:

$$
\mathrm{CO}_{3} \%=\frac{\text { wt. of sample }- \text { wt. of residue }}{\text { wt. of sample }} \times 100
$$

Determination of organic matter contents were made by sequential weight loss at $550^{\circ} \mathrm{C}$ for two hours (Dean, 1974) according the formula:

$$
\text { TOM } \%=\frac{\text { wt. of sample }- \text { wt. of ash }}{\text { wt. of sample }} \times 100
$$


Silicate percentage was calculated from the formula:

Silicate $\%=\frac{\text { wt. of sample }-\left(\text { wt. of } \mathrm{CO}_{3}+\text { wt. of } \mathrm{TOM}\right)}{\text { wt. of sample }} \times 100$

\subsection{Statistical analysis}

Standard deviations of sediment fraction were calculated and the data were treated statistically by one way ANOVA. The means were tested by Duncan using SPSS Ver. 21. The simple linear correlation coefficient (r) was calculated for assessing the relationship between seagrasses distribution and sediment granules, carbonate, silicate and total organic matter.

\section{Results and Discussion}

\subsection{Results}

\subsubsection{Floristic Analysis}

The recorded seagrasses in the studied 40 stands with their families, life forms and floristic categories are presented in Table (1). Five species belonging to 4 genera and 2 families were recorded. Family Cymodoceaceae represented by 1 genera with 2 species (Halophila stipulacea (Forssk.) Asch. and Halophila ovalis (R.Br.) Hook. f.), while family Hydrocharitaceae represented by 3 genera each have one species (Halodule uninervis (Forssk.) Boiss., Thalassodendron ciliatum (Forssk.) and Syringodium isoetifolium (Forssk.) Hartog.). The recorded species are perennials.

The recorded five seagrasses are belonging to the tropical indo-Pasific Bioregion. The spectrum of the global distribution of the recorded seagrasses indicated that each pluriregional and bi-regional seagrasses was represented by 2 species, while mono-regional represented by one species, in addition the recorded seagrass are found together in the tropical indo-Pasific Bioregion.

Table 1. Floristic properties of the recorded species

\begin{tabular}{|l|l|l|l|l|}
\hline species & Family & Habit & Life form & Bioregion \\
\hline $\begin{array}{l}\text { Halophila stipulacea } \\
\text { (Forssk.) Asch., }\end{array}$ & Hydrocharitaceae & Perennial & Helophyte & TA+M+TI-P \\
\hline $\begin{array}{l}\text { Halophila ovals } \\
\text { (R.Br.) Hook. f., }\end{array}$ & Hydrocharitaceae & Perennial & Helophyte & TNP+ TI-P+TSO \\
\hline $\begin{array}{l}\text { Halodule uninervis } \\
\text { (Forssk.) Boiss., }\end{array}$ & Cymodoceaceae & Perennial & Helophyte & TI-P \\
\hline $\begin{array}{l}\text { Thalassodendron ciliatum } \\
\text { (Forssk.) Hartog }\end{array}$ & Cymodoceaceae & Perennial & Helophyte & TI-P+TSO \\
\hline $\begin{array}{l}\text { Syringodium isoetifolium } \\
\text { (Forssk.) Hartog. }\end{array}$ & Cymodoceaceae & Perennial & Helophyte & TI-P+TSO \\
\hline
\end{tabular}




\subsubsection{Vegetation Analysis}

The application of TWINSPAN on the presence of 5 species recorded in the 40 sampled stands of seagrass beds (H. stipulacea, H. uninervis, H. ovalis, Th. ciliatum and $S$. isoetifolium), led to the recognition of 5 vegetation groups (Fig. 2). These groups showed a reasonable segregation along the ordination plane axes 1 and 2 of DECORANA (Fig. 3). The vegetation groups are named by dominant species (the species that have the highest presence percentage).

- H. ovalis (VG A): It includes 3 stands located at Safaga Fishing Port. The average presence of $H$. ovalis was represented by $100 \%$ (table 2 ).

- H. uninervis (VG B): It includes 16 stands and 3 species. Two stands located at NOIF (Hurghada harbor), one at Wadi Quiah site, 8 at Gasous and 5 at Safaga Fishing Port. In this group, $H$. uninervis was represented by $100 \%$ presence, and the associated seagrasses H. stipulacea and H. ovalis were represented by 38 and $19 \%$, respectively.

- H. stipulacea and H. ovalis (VG C): It includes 1 stand located at the NOIF in Hurghada harbor. Each of the two species was represented by $100 \%$ presence.

- H. stipulacea (VG D): This group contains 16 stands; more than half of the stands located at Hurghada Harbor (9 stands), 3 stands at Wadi Quiah and 2 stands at Gasous. $H$. stipulacea is representing by $100 \%$ presence and the associated seagrass Syringodium isoetifolium by $6 \%$.

- Thalassodendron ciliatum (VG E): It includes 4 stands, 3 of them located at Wadi Quiah and the $4^{\text {th }}$ at Shery (Hurghada). Th. ciliatum represented by $100 \%$ presence and the associated species (H. stipulacea) by $25 \%$ (table 2 ). 


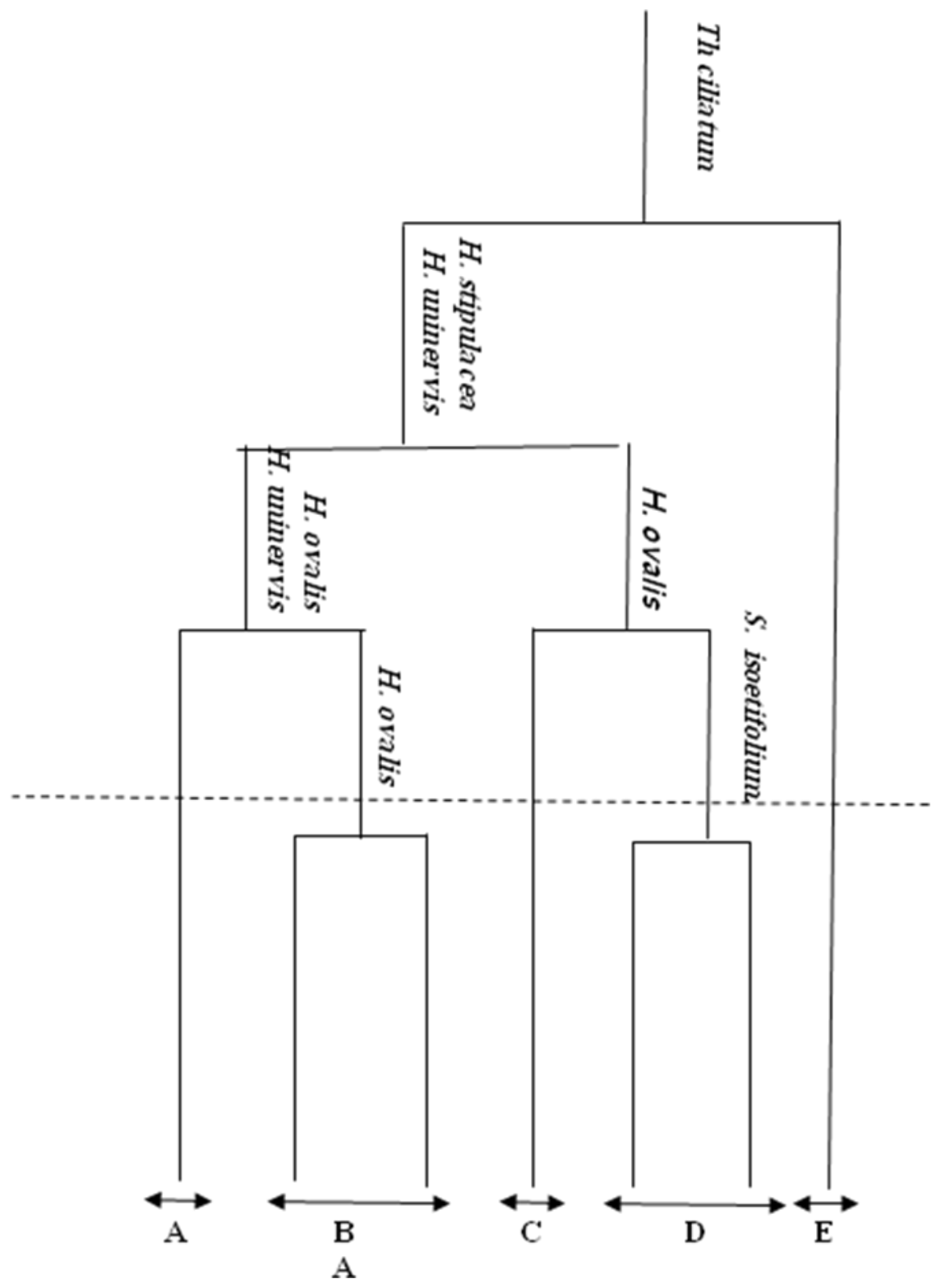

Fig. 2: The dendrogram resulting from the application of TWINSPAN on the 40 sampled stands. The names of these groups are: A: H. ovalis, B: H. uninervis, C: H. stipulacea and $\boldsymbol{H}$. ovalis, D: H. stipulacea and E: Th. ciliatum.

\subsubsection{Sediment granules}

Granules analysis of the 40 sediment samples collected from four locations showed high variation among the stands in the same site.

The data in table (3) show significant variation in sediment granules among the four sites. It is noticed that the sediment of studied sites mainly constructed from fine granules (fine sand, silt and clay) ranged between 92.20 to $62.91 \%$. Gasous site contains the highest percentage of coarse sand (14.68\%), while Safaga fishing Port contains the lowest average of 
coarse and medium sand (0.94 and 6.86\%, respectively) but contains the significant highest average of fine granules (96.20\%). Hurghada and Wadi Quiah sediments contain approximately similar percentages of medium sand (25.2 and 30.22\%) and fine granules (62.91 and 64.58\%). Gasous site contains significant highest percentage of carbonates $(69.21 \%)$ but contains the lowest percentages of silicates and total organic matter (26.69 and $4.10 \%$, respectively). On the other hand, Wadi Queh contains the significant lowest percentage of carbonates $(29.75 \%)$ and the significant highest percentage of silicate and total organic matter.

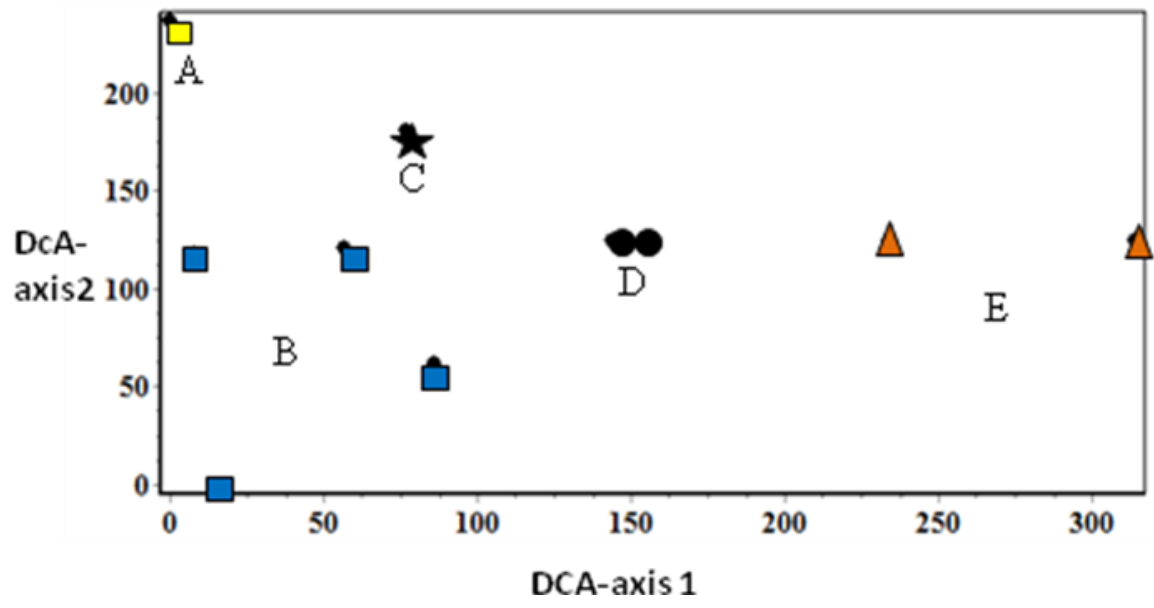

Fig. 3: DCA ordination of the 8 vegetation groups identified after the application of TWINSPAN on the 40 sampled stands. The names of these groups are: A: H. ovalis, B: H. uninervis, C: H. stipulacea and H. ovalis, D: H. stipulacea and E: Th. ciliatum.

Table 2: Average presence of the seagrasses species in five vegetation groups produced from TWINSPAN

\begin{tabular}{|l|c|c|c|c|c|}
\hline Stands & VG A & VG B & VG C & VG D & VG E \\
\hline H. stipulacea & & 38 & 100 & 100 & .25 \\
\hline H. uninervis & & 100 & & & \\
\hline H. ovalis & 100 & 19 & 100 & & \\
\hline Th. ciliatum & & & & & 100 \\
\hline S. isoetifolium & & & & 6 & \\
\hline No of species & $\mathbf{1}$ & $\mathbf{3}$ & $\mathbf{2}$ & $\mathbf{2}$ & $\mathbf{2}$ \\
\hline No of stands & $\mathbf{3}$ & $\mathbf{1 6}$ & $\mathbf{1}$ & $\mathbf{1 6}$ & $\mathbf{4}$ \\
\hline
\end{tabular}

The simple correlation coefficient between sediment fractions and seagrass distribution is analyzed and tabulated in table (4). The results detected that $H$. stipulacea has high significant positive correlation with carbonates $(\mathrm{r}=0.56)$, but highly significant negative correlation with silicates $(\mathrm{r}=-0.56)$. On the other hand, H. uninervis and $H$. ovalis have negative correlation with Medium sand $(r=-0.44 * *$ and -0.296$)$ and carbonates $(r=-0.33 *$ 
and -0.28$)$ but they had positive correlation with fine granules $\left(\mathbf{r}=0.45^{*}\right.$ and 0.26$)$. Th. ciliatum seagrass show significant negative correlation with total organic matter of the sediment.

Table 3: Average ( \pm standard deviation) of granules groups of 40 stands sediment of located at Hurghada and Safaga Harbors.

\begin{tabular}{|c|c|c|c|c|c|c|}
\hline & C. sand\% & M. sand\% & F. granules\% & $\mathrm{CO}_{3}{ }^{-\cdots} \%$ & Silicates\% & TOM\% \\
\hline Hurghada & $\begin{array}{c}11.37 \mathbf{a} \\
\pm 7.69\end{array}$ & $\begin{array}{l}25.22 \text { a } \\
\pm 15.33\end{array}$ & $\begin{array}{l}\mathbf{6 2 . 9 1} \mathbf{b} \\
\pm 19.60\end{array}$ & $\begin{array}{l}61.78 \mathbf{b} \\
\pm 11.05\end{array}$ & $\begin{array}{l}32.24 \mathbf{c} \\
\pm 11.98\end{array}$ & $\begin{array}{l}5.98 \mathbf{b} \\
\pm 1.41\end{array}$ \\
\hline $\begin{array}{l}\text { Safaga Fishing } \\
\text { Port }\end{array}$ & $\begin{array}{l}\mathbf{0 . 9 4} \mathbf{c} \\
\pm 0.84\end{array}$ & $\begin{array}{l}\mathbf{6 . 8 6} \mathrm{c} \\
\pm 5.39\end{array}$ & $\begin{array}{c}92.20 \mathrm{a} \\
\pm 5.59\end{array}$ & $\begin{array}{c}50.27 \pm \mathbf{c} \\
12.61\end{array}$ & $\begin{array}{l}41.90 \mathbf{b} \\
\pm 27.73\end{array}$ & $\begin{array}{l}7.83 \mathrm{a} \\
\pm 1.02\end{array}$ \\
\hline Gasous & $\begin{array}{l}\mathbf{1 4 . 6 8} \text { a } \\
\pm 12.78\end{array}$ & $\begin{array}{c}15.74 \mathbf{b} \\
\pm 9.75\end{array}$ & $\begin{array}{c}\mathbf{6 9 . 5 8} \\
\pm 18.78 \mathrm{~b}\end{array}$ & $\begin{array}{c}69.21 \mathbf{a} \\
\pm 3.44\end{array}$ & $\begin{array}{c}26.69 \mathbf{c} \\
\pm 3.32\end{array}$ & $\begin{array}{l}4.10 \mathrm{~b} \\
\pm 0.44\end{array}$ \\
\hline Wadi Queh & $\begin{array}{l}5.25 \mathbf{b} \\
\pm 4.24\end{array}$ & $\begin{array}{c}\mathbf{3 0 . 6 7} \mathbf{a} \\
\pm 4.37\end{array}$ & $\begin{array}{c}\mathbf{6 4 . 0 7} \mathbf{b} \\
\pm 4.42\end{array}$ & $\begin{array}{c}29.75 \mathbf{d} \\
\pm 8.59\end{array}$ & $\begin{array}{l}61.64 \mathbf{a} \\
\pm 8.52\end{array}$ & $\begin{array}{l}8.61 \mathrm{a} \\
\pm 1.18\end{array}$ \\
\hline
\end{tabular}

Table 4. Simple linear correlation coefficient (r) between sediment properties and seagrasses distribution

\begin{tabular}{|l|c|c|c|c|c|c|}
\hline & CS & MS & FS & CO $^{-{ }^{-}}$ & Silicates & TOM \\
\hline H. stipulacea & 0.161 & 0.324 & -0.318 & $0.560^{* *}$ & $-0.55-^{* * *}$ & -0.258 \\
\hline H. uninervis & -0.059 & $-0.437-^{* *}$ & $0.349^{*}$ & $-0.33-^{*}$ & 0.322 & 0.251 \\
\hline H. ovalis & -0.250 & -0.197 & 0.264 & -0.248 & 0.237 & 0.213 \\
\hline Th. ciliatum & -0.026 & 0.224 & -0.145 & 0.283 & -0.253 & $-0.415-^{*}$ \\
\hline S. isoetifolium & 0.059 & 0.232 & -0.247 & 0.180 & -0.173 & -0.141 \\
\hline
\end{tabular}

\subsection{Discussion}

The investigation of seagrass distribution globally is a complex and confounding task due to the wide range of species diversity patterns and areas where seagrasses are as yet undocumented as well as the fact that seagrass habitat is ever-changing.

Seagrass beds are an ecologically significant marine habitat providing food and shelter for bottom dwelling animals. Seagrass beds are covering about $0.1-0.2 \%$ of the global ocean floor. Important ecological and economic functions of seagrass beds have been widely acknowledged, notably their importance to fisheries (Jackson et al., 2002) and their role in preventing coastal erosion and siltation of coral reefs (Duarte, 2002). Despite its value and importance they are very sensitive and its health is affected by a wide range of natural and human disturbances that occur at a range of spatial and temporal scales.

Despite the importance of the seagrass meadows, a relatively little information is available about its distribution on the Egyptian Red Sea coast. The number of species of seagrass recorded from the shallow areas of the Red Sea Coast during the last decades are 
never exceed 11 species (Wahbeh, 1984; Aleem, 1984) where, in the recent publications only 6 or 7 species are commonly seen specially in the northern part of the Red Sea (Geneid, 1995).

Five seagrass species were recorded in the studied area (Halophila stipulacea, Halodule uninervis, Halophila ovails, Thalassodendron ciliatum and Syringodium isoetifolium) similar to the findings of Geneid (1995 and 2009), Mohamed (2010), and Khalafallah et al. (2015). The present data indicated that $H$. stipulacea and H. ovalis seagrass have the highest spatial distribution in Hurghada and Safaga Harbors according to their presence in the studied sited. In addition, H. stipulacea seagrass are found in different depths ranged from 0.6 (in NOIF, Shery, Safaga Fishing Port, Gasous and Wadi Quiah) to 21m (the other stands in Hurghada).

Khalafallah et al. (2015) recorded S. isoetifolium in the General Beach of Safaga by one individual, this species not recorded in recent studied sites located at Safaga Harbor but recorded it in one stand located at Hurghada Harbor at depth more than $20 \mathrm{~m}$ by one individual also. The present and the previous results indicated that this species has low spatial distribution and low density in the Hurghada and Safaga Harbors.

The results of the present investigation are in agreement with the documentation of Short et al. (2007) for the five seagrasses. In the Tropical Indo-Pacific region, H. stipulacea seagrass is extended from estuaries to very deep clear water $(70 \mathrm{~m})$, while $H$. ovalis and $H$. uninervis are extended from estuaries to shallow coastal regions. In addition, Th. Ciliatum and S. isoetifolium seagrasses are found only in the shallow coastal regions.

The recorded species have important role in different fields as in feeding and medicine in addition to their ecological value, on the other hand, their impacts on the presence of other seagrasses communities.

Short et al. (2010) found H. stipulacea in the Indian Ocean is an invasive species in the Mediterranean and Caribbean. In addition, Sghaier et al. (2014) found that C. nodosa has disappeared as a result of introducing H. stipulacea in their habitats. Abd El-Hady (2012) found the aqueous extract of $H$. stipulacea exhibited good antifungal activity and its methanolic extract had moderate antioxidant activity, thus makes it interesting for investigation of its natural products components.

Baehaki et al. (2016) found that the methanolic extract of $H$. uninervis has bacterial activity against Gram-positive bacteria higher than that of these Gram-negative bacteria. These findings suggest that antimicrobial activity of $H$. uninervis extract may be primarily due to the presence of tannins and phenolic compound. Their results also showed content of 
phytochemical compounds of methanolic extract of $H$. uninervis are flavonoids, alkaloids, steriod and phenols. Antioxidant activity with DPPH method (IC50) of H. uninervis was $1.575 \mathrm{ppm}$. The highest of reducing power of H. uninervis was 1.381 .

Halophila ovalis seagrass is among the favourite food of dugongs so it is also sometimes called Dugong grass (Waycott et al., 2004). In addition, Girija et al. (2013) found that methanolic extract of Halophila ovalis has antioxidant effect.

Th. ciliatum is one of the most common and longest seagrasses along the Egyptian Red Sea. It is characterized by many 'tannin cells' in its leaves, more than in any other seagrass (Lipkin, 1988), which means a high phenolic content. In addition, Hamdy et al. (2012) isolate and identify five flavonoids (rutin, asebotin, 3-hydroxyasebotin, quercetin-3-O$\beta$-D-xylopyranoside, and a racemic mixture of catechin) and caffeic acid from seagrass, Th. ciliatum, collected from the Hurghada region in Egypt. They found that these compounds have antioxidant, cytotoxic and antiviral activities. Girija et al. (2013) found that methanolic extract of Th. ciliatum has antioxidant effect

Dugongs graze on $\mathbf{S}$. isoetifolium seagrass where there are no Halophila or Halodule seagrasses available. So it is also sometimes called Dugong grass. In addition, Girija et al. (2013) found that methanolic extract of this seagrass has antioxidant effect. S. isoetifolium is listed as 'Endangered' on the Red List of threatened plants of Singapore.

Sediment represents the main source of nutrients to the marine plants and it has main impact on seagrass distribution. Sediment granules analysis showed high variation among granules percentage in stands in the same stand. This result indicated that there was heterogeneous distribution of the sediments. This heterogeneity may be due to the heterogeneity of their baseline. Luo et al. (2007) in their study, have found heterogeneity in the concentrations of heavy metals in sediment samples collected from the same site, they have attributed that to the lack of homogeneity in the sediment components in the same site.

Bos et al., (2007) illustrated that the wide-spreading of seagrass carpets are modifying the sediment composition by its mere presence. Brito et al. (2016) recorded that Halodule wrightii was growing in sheltered to moderately sheltered areas in substrates that range between sand and mud. (Roca $\boldsymbol{e t}$ al., 2014) documented that sediment was mainly composed of fine particles that spread over the seagrass meadows. Lewis et al. (2007) classified the sediments of the seagrass habitats at Florida, USA, as silty sand to sand nature with percentage of silt between $1-11 \%$ and sand between $86-99 \%$.

In the sheltered areas, sediment dynamics are dominated by internal re-suspension due to wind-waves and tidal currents. As a result of allowing for advection of sediment, bed grain 
size distributions and resuspension mechanisms ultimately both play important roles in determining the transport and light environment (Carr et al., 2015). Reise and Kohlus (2008) and van Katwijk et al. (2009) reported that the seagrasses are often growing in compact clay banks and can grow at less sheltered sites. Van Katwijk and Wijgergangs (2004) were described the sediments of seagrass habitats of Zostera marina in the Wadden Sea as mud and muddy sand.

Serrano et al. (2016) found that the Posidonia australis meadows at Oyster Harbor, Australia are mainly composed of siliciclastic (av. 64\%) and biogenic carbonate percentage was ranged 14 to $34 \%$. (av. 26\%). sediments and to a lesser extent of organic matter ( 10\%). Madkour et al. (2014) reported that carbonate percentage in the mangrove sediments was varied between $4.7 \%$ and $64.9 \%$ attributed to the relatively high terrigenous input produced from sporadic flash floods plus the low contribution of carbonate sediments produced by the reef community. According to Dar et al. (2016a), the average $\mathrm{CO}_{3} \%$ in un-vegetated locations along the Red Sea was varied between $42.42 \%$ and $75.49 \%$.

Comparing between the sediment analysis in the vegetated areas and non-vegetated areas indicating that seagrasses can alter the sediment composition. Furthermore, the sediment composition controlled the distribution of seagrasses. It is clear from the results of the correlation analysis which indicated that $H$. stipulacea seagrass prefers sediments contain high percentages of carbonates and low percentage of silicates, while $H$. uninervis and $H$. ovalis prefer sediments contains high percentage of fine sand.

\section{Conclusion}

The recent study presented as a data base for seagrass vegetation, distribution and its relationships with sediments type. The results can be summarized as following:

- Five species of seagrasses had been recorded in Hurghada and Safaga harbors belonging to two families.

- All recorded species are mainly belonged to tropical indo-pacific bioregion.

- Five vegetation groups were results from TWINSPAN analysis and sorted by DCA analysis.

- H. stipulacea seagrass has the highest spatial distribution species in the studied area.

- Distribution of the five seagrasses affected by the sediment texture, on the other hand presence of seagrasses can alter sediment texture and composition. 
- The presented data are significant in seagrass management and conservation.

- Recent techniques as remote sensing integrated with field survey is recommended for monitoring these communities to give a clear view on spatial distribution of seagrasses on a large scale along red Sea.

\section{References}

Abd El-Hady, H.H. Hamed, E.R. and Shehata A.N. Molecular Identification, Antimicrobial, and Antioxidant Activities of the Tropical Seagrass Halophila stipulacea Grown in El-Bardawil Lake, Egypt. Australian Journal of Basic and Applied Sciences, 6 (12): 474-481(2012).

Aleem, A.A. ,Distribution and ecology of seagrass communities in the western Indian Ocean. Deep-sea Res, 31: 919-933(1984).

Baehaki. A, Supriadi, A. and Pratama, M.C. ,Antioxidant Activity of Methanol Extract of Halodule uninervis Seagrass from the Coastal of Lampung, Indonesia. Research Journal of Pharmaceutical, Biological and Chemical Sciences, 7(3): 1173-1177(2016).

Barbier, E.B., Hacker, S.D., Kennedy, C., Koch, E.W., Stier, A.C. and Silliman, B.R. The value of estuarine and coastal ecosystem services. Ecol Monogr, 81: 169193(2011).

Bjork, M., Short, F.T., McLeod, E., Beer, S. Managing Seagrasses for Resilience to Climate Change . IUCN, Gland, Switzerland(2008).

Bologna, A.X. and Suleski, A.J. Assessment of seagrass floral community structure from two Caribbean marine protected areas. Gulf and Caribbean Research, 25: 19-27(2013).

Bos, A.R., Bouma, T.J., de Kort, G.L.J., van Katwijk, M.M. Ecosystem engineering by annual intertidal seagrass beds: sediment accretion and modification. Estuarine Coastal and Shelf Science 74, 344-348(2007).

Boulos, L. Flora of Egypt, Volume 4: Monocotyledons (Alismataceae-Orchidaceae). Al Hadara Publishing, Cairo, Egypt(2005).

Bracken MES, Gonzalez-Dorantes CA, and Stachowicz JJ. Whole-community mutualism: associated invertebrates facilitate a dominant habitat-forming seaweed. Ecology 88: 2211-19(2007).

Brito, G.B., Souza, T.L., Costa, F.N., Moura, C.W.N. and Korn, M.G.A. Baseline heavy elements in the seagrass Halodule wrightii Aschers (Cymodoceaceae) from Todos os Santos Bay, Bahia, Brazil. Marine Pollution Bulletin, 104: 335-342(2016). 
Bulleri, F., and Chapman. M.G. The introduction of coastal infrastructure as a driver of change in marine environments. J Appl Ecol 47: 26-35(2010)..

Carr, J.A., D’Odorico, P., M.c. Glathery, K.J. and Wiberg, P.L. Spatially explicit feedbacks between seagrass meadow structure, sediment and light: Habitat suitability for seagrass growth.AdvancesinWater Resources000:1-11(2015). doi:10.1016/j.advwatres.2015.09.001

Dar, M.A., El-Metwally, M.E.A. and El-Moselhy, Kh.M.I. Distribution patterns of mobile heavy metals in the inshore sediments of the Red Sea. Arab J Geosci, 9: 221(2016).

Dayton, P.K. Toward an understanding of community resilience and the potential effects of enrichments to the benthos at McMurdo Sound, Antarctica. In: Parker BC (Ed). Proceedings of the colloquium on conservation problems in Antarctica. Lawrence, KS: Allen Press(1972).

Dean, W.E. Determination of carbonate and organic matter in calcareous sediments and sedimentary rocks by loss in ignition: comparison with other methods. J. Sediment. Petrol., 44: 242-248(1974)..

den Hartog, C. The Seagrasses of the World . North-Holland Publ. Co., Amsterdam, pp. 275 (1970).

Duke, N.C., Meynecke, J.O., Dittmann, S., Ellison, A.M., Anger, K., Berger, U., Cannicci, S., Diele, K., Ewel,K.Cm., Field, C.D., Koedam, N., Lee, S. Y., Marchand, C., Nordhaus, I. and Dahdouh-Guebas, F. A world without mangroves. Science, 317: 41(2007).

El Shaffai, A. Field Guide to Seagrasses of the Red Sea Rouphael, A. and Abdulla, A., eds. First Edition. Gland, Switzerland: IUCN and Courbevoie, France(2011). .

Ellison, A.M., Bank, M.S., Clinton, B.D., et al. Loss of foundation species: consequences for the structure and dynamics of forested ecosystems. Front Ecol Environ, 3: 479$86(2005)$.

English, S., Wilkinson, C. and Basker, V. "Survey manual for tropical marine resources" (2nd Ed). Australian Institute of Mar. Sci.. Townsville, pp.119-195(1997).

Folk, R.L. Petrology of sedimentary rocks. University of Texas, Hemphill Pub. Co., 182p(1974).

Fried, G., Norton, L.R. and Reboud, X. Environmental and management factors determining weed species composition and diversity in France. Agri. Ecosys. Environ. 128: 68-76(2008). 
Gauch, H.G. and Whittaker, R.H. Hierarchical Classification of Community Data. J. Ecol., 69: 135-152(1981)..

Geneid, Y.A. Ecological study on the seagrass at some Egyptian Red Sea Coat. MSc Thesis, Oceanography Depart. Faculty of Science, Swez Canal University (1995).

Geneid, Y.A. Distribution of seagrass species along the Egyptian Red Sea coast. Egyptian Journal of Aquatic Research ,35 (1) :58-68(2009).

Girija K., Parthiban C., Hemalatha A., Saranya C., Anantharaman P Evaluation of antioxidant activities and preliminary phytochemical analysis of seagrasses Halodule pinifolia, Halophila ovalis and Syringodium isoetifolium. The Journal of Phytochemistry. Photon, 114: 181-187(2013).

Green, E.P., and Short, F.T. World Atlas of Seagrasses . Published in association with UNEP-WCMC by the University of California Press, California. Berkeley, USA.298 pp (2003) .

Hamdya, A.A. Mettwallya, W.S. A. and Abou El Fotouh, M. Bioactive Phenolic Compounds from the Egyptian Red Sea Seagrass Thalassodendron ciliatum. Z. Naturforsch. 67 c, 291 - 296 (2012).

Heck, K.L., Carruthers, T.J., Duarte, C.M., Hughes, A.R., Kendrick, G.A., Orth, R.J., Williams, S.L. (2008). Trophic transfers from seagrass meadows subsidize diverse marine and terrestrial consumers. Ecosystems 11, 1198-1210.

Hill, M.O. TWINSPAN: A FORTRAN Program for Arranging Multivariate data in an Ordered To-way Table by Classification of the Individual and Attributes. Cornell Univ., Ithaca, New York, 90 pp(1979a).

Hill, M.O. DECORANA: AFORTRAN Program for Detrended Correspondence Analysis and Reciprocal Averaging: Cornell Univ., Ithaca, New York, 52 pp(1979b).

Hill, M.O. and Gauch, H.G. Detrended Correspondence Analysis, an Improved Ordination Technique. Vegetatio, 42: 47-58(1980).

Hughes, A.R., Williams, S.L., Duarte C.M, Heck, K.L., and Waycott, M. Associations of concern: declining seagrasses and threatened dependent species. Front Ecol Environ, 7(5): 242-246(2009).

Kandi, B., Sahu, S.C., Dhal, N.K. and Mohanty, R.C. Species diversity of vascular plants of Sunabeda wildlife sanctuary, Odisha, India. New York Sci. J. 4(3): 1-9(2011).

Khalafallah, A.A., Sheteawi, S.A., Geneid, Y. A. and Essa B.S. Assessment the ecological and physiological status of seagrasses in representative habitats at hurgada and safaga provinces, Red Sea Coast, Egypt. Egyptian journal of Botany, in press. 
Lewis, M.A., Dantin, D.D., Chancy, C.A., Abel, K.C. and Lewis, C.G. (2007). Florida seagrass habitat evaluation: a comparative survey for chemical quality. Environ. Pollut., 146: 206-218(2015).

Lipkin, Y. Thalassodendretum ciliati in Sinai (northern Red Sea) with special reference to quantitative aspects. Aquat. Bot., 3: 125 - 139 (1988). .

Madkour, H.A., Mansour, A.M., Ahmed, A.N, and El-Taher, A. Environmental texture and geochemistry of the sediments of a subtropical mangrove ecosystem and surrounding areas, Red Sea Coast, Egypt. Arab J Geosci, 7: 3427-3440 (2014).

Mohamed, E.O. Ecological Studies on Fauna Associated with Seagrass Habitat at HurghadaRed Sea. M. Sc. Zoology Department, Faculty of Science, Al Azhar University (2010).

Okbah, M.A., Shata, M.A. and Shridah, M.A. Geochemical forms of heavy metals in mangrove sediments - Red Sea (Egypt). Chemistry and Ecology, 21(1): 23-36 (2005).

Orth, R.J., Carruthers, T.J.B., Dennison, W.C., et al. A global crisis for seagrass ecosystems. BioScience, 56: 987-96 (2006).

Reise, K. and Kohlus, J. Seagrass recovery in the Northern Wadden Sea? Helgoland Marine Research, 62: 77-84(2008).

Roca, G.; Romero, J.; Columbu, S.; Farina, S.; Pagès, J. F.; Gera, A. Inglis, G. and, Alcoverro, T. Detecting the impacts of harbour construction on a seagrass habitatand its subsequent recovery. Ecological Indicators 45: 9-17(2014).

Serrano, O., Mateo, M.A., Dueñas-Bohórquez, A., Renom, P., López-Sáez, J.A. and Martinez-Cortizas, A. Posidonia oceanica marine coastal sedimentary record: a Holocene archive of heavy metal pollution from NE Spain. Sci. Total Environ, 409: 4831-4840 (2011).

Shehata, H.S. and Galal, T.M. (2015). Factors affecting distribution and associated species of Malva parviflora L. in the Nile Delta, Egypt. Weed Biol Manage. 15:42-52.

Short, F., Carruthers, T., Dennison, W. and Waycott, M. Global seagrass distribution and diversity: A bioregional model. Journal of Experimental Marine Biology and Ecology, 350: 3-20(2007).

Short, F.T., Carruthers, T.J.R., Waycott, M., Kendrick, G.A., Fourqurean, J.W., Callabine, A., Kenworthy, W.J. \& Dennison, W.C. Halophila stipulacea. The IUCNRedListofThreatenedSpecies2010:e.T173319A6989685.http://dx.doi.org/10.230 5/IUCN.UK.2010-3.RLTS.T173319A6989685.en (2010). 
Short, F.T., McKenzie, L.J., Coles, R.G., Vidler, K.P., Gaeckle, J.L. Seagrass Net Manual for Scientific Monitoring of Seagrass Habitat, Worldwide edition. University of New Hampshire Publication. 75 pp(2006).

Stachowicz, J.J. and Hay, M.E. Facultative mutualism between an herbivorous crab and a coralline alga: advantages of eating noxious seaweeds. Oecologia, 105: 377-87(1996)..

van Katwijk, M.M. and Wijgergangs, L.J.M. Effects of locally varying exposure, sediment type and low-tide water cover on Zostera marina recruitment from seed. Aquatic Botany, 80: 1-12(2004).

van Katwijk, M.M., Bos, A.R., de Jonge, V.N., Hanssen, L.S.A.M., Hermus, D.C.R. and de Jong, D.J. Guidelines for seagrass restoration: Importance of habitat selection and donor population, spreading of risks, and ecosystem engineering effects. Marine Pollution Bulletin, 58: 179-188 (2009)..

Wahbeh, M.I. Distribution, Biomass, Biometry and some associated fauna of the seagrass community in the Jordan Gulf of Aqaba., Proc. 4th. Int. Coral Reef Symp. Manila, Vol.2: 453-459(1984).

Walker, D.I., Kendrick, G.A., and McComb, A.J. Decline and recovery of seagrass ecosystems - the dynamics of change. In: Larkum AWD, Orth RJ, and Duarte CM (Eds). Seagrasses: biology, ecology, and conservation. Dordrecht, Netherlands: Springer (2006).

Waycott, M., Duarte, C.M., Carruthers, T.J.B., Orth, R.J., Dennison, W.C., Olyarnik, S., Calladine, A., Fourqurean, J.W., HeckJr., K.L., Hughes, A.R., Kendrick, G.A., Ken- worthy, W.J., Short, F.T. and Williams, S.L. Accelerating loss of seagrasses across the globe threatens coastal ecosystems. Proc. Nat. Acad. Sci. U.S.A., 106: 1237712381(2009).

Waycott, Michelle et. al. AGuide to Tropical Seagrasses of the Indo-West Pacific. 2004. James Cook University. 72 pp (2004). 


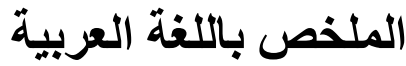

\section{تركيب وتحليل الغطاء النباتي وتوزيع الحشائش البحرية وعلاقتهم بنوعية الرواسب فى قطاعى الغردقة وسفاجا بالبحر الأحمر}

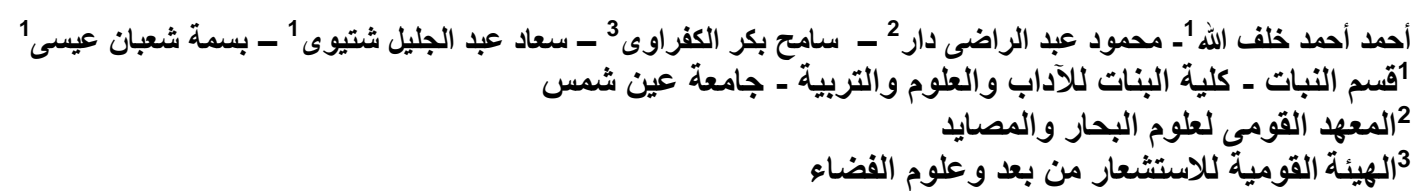

تهدف الدراسة الحالية إلى التعرف على التركيب الفلورى وتحليل الغطاء النباتي وتوزيع الحشائش البحرية

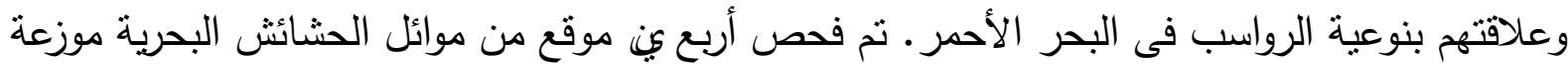

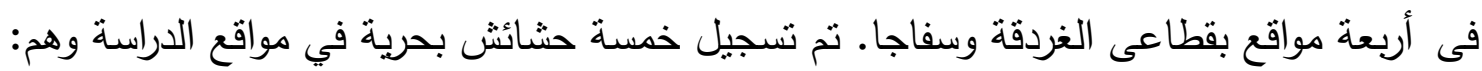

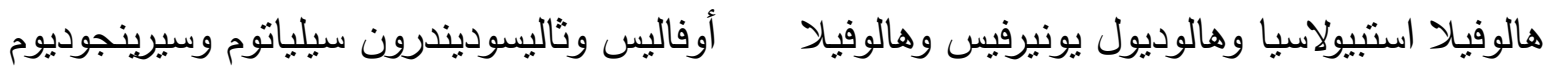

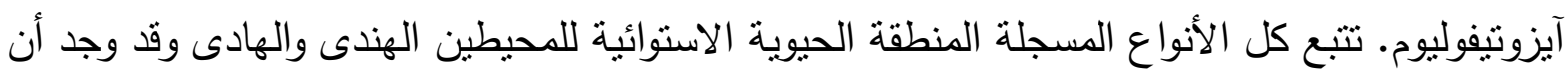
غالبية الحشائش المسجلة تتواجد فى أكثر من منطقة حيوية على مستوى العالم بينما النوع هالوديول يونيرفيس لا ينوجد إلا فى المنطقة الحيوية الاستوائية للمحيطين الهندى والهادى. بتطبيق التحليل الدليلى

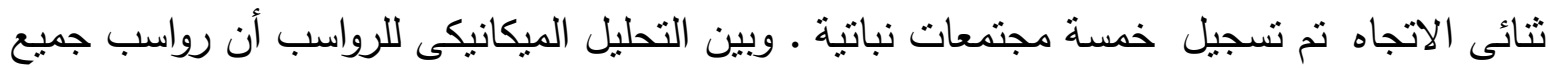

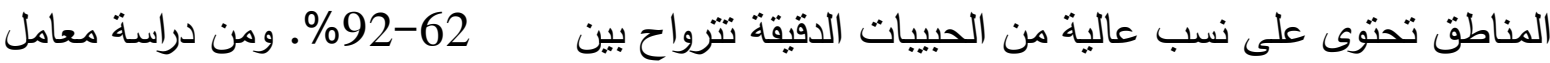
الارتباط بين نسبة نواجد الحشائش المسجلة ونوعية الرواسب وجد أن هناك ارتباط بين طبيعة الرواسب

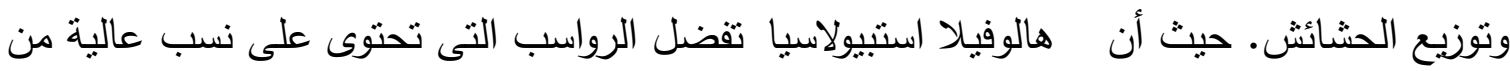
الكربونات بالإضافة إلى أن هالوديول يونينرفس وهالوفيلا أوفاليس تفضل الرواسب التى تحنوى على نسب عالية من الحبيبات الدقيقة. تعتبر هذه النتائج ذات أهمية كقاعدة بيانات لإدارة النظم البيئية لهذه

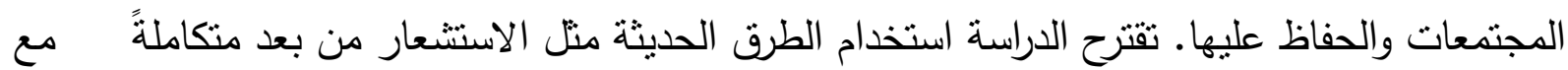
المسح الميداني لمتابعة رصد هذه المجتمعات بجانب إعطاء رؤية واضحة على التوزيع التوسعى لموائل الحشائش البحرية على نطاق واسع على طول البحر الأحمر. 